\title{
Pendampingan Pembuatan Bahan Ajar Berbasis Kurikulum 2013 Bagi Guru Administrasi Perkantoran
}

\author{
Choirul Nikmah \\ Universitas Negeri Surabaya, choirulnikmah@unesa.ac.id \\ Triesninda Pahlevi \\ Universitas Negeri Surabaya, triesnindapahlevi@unesa.ac.id \\ Durinda Puspasari \\ Universitas Negeri Surabaya, durindapuspasari@unesa.ac.id \\ Durinta Puspasari \\ Universitas Negeri Surabaya, durintapuspasari@unesa.ac.id \\ Joni Susilowibowo \\ Universitas Negeri Surabaya, jonisusilowibowo@unesa.ac.id
}

\begin{abstract}
Changing of Curriculum involves change of substance, implementation, and evaluation. Teacher must have better preparation to improve learning quality. Around 73\% of school in Jombang, from elementary to high school, had applied curriculum of 2013. However, teacher faces difficulty to prepare teaching material since there are several new subjects that never been taught previously in Vocational High School for office administration department. Besides, there are many books based on curriculum of 2013 are not sold freely. Thus, to solve those problems, teacher training and mentoring to create teaching material based curriculum 2013 needs to be held. It uses training and mentoring method. The training aims to enhance teacher competency to create teaching material, in the form of module, based on curriculum of 2013. The training result is module based on curriculum of 2013.
\end{abstract}

Keywords: Teaching material, Module, Curriculum of 2013, Training 


\section{PENDAHULUAN}

\section{Analisis Situasi}

Kurikulum merupakan sebuah wadah yang akan menentukan arah pendidikan. Kurikulum disusun berdasarkan kebutuhan dan perkembangan masyarakat secara global. Kurikulum dibuat oleh lembaga penyelenggara pendidikan yang terdiri dari rancangan pembelajaran. Kurikulum dirancang sebagai alat untuk mencapai tujuan pendidikan nasional. Penyempurnaan kurikulum disusun dengan tujuan menyesuaikan kebutuhan yang terjadi di masyarakat. Kurikulum terbaru merupakan hasil upaya penyempurnaan dari kurikulum sebelumnya.

Kurikulum 2004 dikenal dengan istilah Kurikulum Bebasis Kompetensi (KBK). Pada kurikulum ini mengandung tiga unsur pokok, yaitu; (1) pemilihan kompetensi sesuai; (2) spesifikasi indikatorindikator evaluasi untuk menentukan keberhasilan pencapaian kompetensi; (3) dan pengembangan pembelajaran. KBK menekankan pada kompetensi siswa secara individu maupun secara klasikal dengan melihat hasil belajar disertai keberagaman. Penggunaan pendekatan dan metode yang digunakan oleh guru bervariasi. Inovasi kurikulum selanjutnya dikenal dengan

Available at

http://journal.unj.ac.id/unj/index.php/jpm kurikulum 2006 atau disebut Kurikulum Tingkat Satuan Pendidikan (KTSP). Pemerintah menerapkan Standar Kompetensi dan Kompetensi Dasar, dan guru diberikan kebebasan untuk mengembangkan sendiri perangkat pembelajarannya.

Pengganti kurikulum 2006 atau KTSP adalah kurikulum 2013. Aspek penilaian yang diukur pada kurikulum ini adalah aspek pengetahuan (kognitif), aspek keterampilan (afektif), dan aspek sikap (psikomotorik). Kurikulum ini dinilai masih terburu-buru dan kurang matang seperti kurilum sebelumnya (Alawiyah, 2014). Perubahan pada kurikulum ini meliputi, sisi subtansi, implementasi, sampai evaluasi. Pemerintah telah menyiapkan perangkat dan guru hanya bertindak sebagai motivator. Untuk itulah guru harus dipersiapkan dengan baik agar kualitas pembelajaran menjadi lebih baik.

Sejauh ini kondisi yang ada di Kabupaten Jombang, sebanyak 73\% sudah melaksanakan kurikulum 2013 dari sekolah tingkat dasar sampai atas. Berdasarkan hasil wawancara dengan ketua MGMP Administrasi Perkantoran dan beberapa guru di Kabupaten Jombang, menyatakan bahwa mereka mengalami kesulitan menyusun bahan ajar karena banyak materi baru dan 
kesesuaian dengan tujuan pembelajaran pada masing-masing mata pelajaran. Sedangkan bahan ajar yang mereka gunakan adalah modul. Menurut kurniasih dkk (2014) bahan ajar dapat berupa handout, buku, modul, brosur, foto atau gambar. Modul yang mereka gunakan masih berdasarkan kurikulum KTSP dan untuk mata pelajaran baru mereka hanya menfoto kopi sumber yang berasal dari internet atau buku-buku di perpustakaan.

Untuk itulah diberikan pelatihan pengembangan bahan ajar berbasis kurikulum 2013 sebagai dasar untuk meningkatkan kualitas pembelajaran bagi guru di Kabupaten Jombang. Pengembangan bahan ajar ini berupa modul pembelajaran yang disesuaikan dengan kebutuhan siswa dan disesuaikan dengan tujuan pembelajaran pada kurikulum 2013. Setelah pelatihan ini diharapkan dapat mempermudah guru selama proses pembelajaran di dalam kelas.

\section{Perumusan Masalah}

Berdasarkan hasil interview antara tim pelaksana PKM dengan guru SMK Administrasi Perkantoran didapatkan informasi bahwa pembelajaran di kelas sering kali mengalami kendala. Hal tersebut dikarenakan bahan ajar di kelas belum memadai. Selain itu belum banyak buku

Available at http://journal.unj.ac.id/unj/index.php/jpm khususnya terkait kompetensi keahlian administrasi perkantoran yang di jual dipasaran. Kondisi diatas mengakibatkan guru kesulitan untuk memperoleh materi yang diperlukan dalam pembelajaran. Oleh karena itu diperlukan kemandirian guru untuk dapat menyusun bahan ajar, dalam hal ini adalah modul sehingga kualitas pembelajaran di kelas dapat ditingkatkan.

\section{Tujuan dan Manfaat}

Pendampingan pembuatan bahan ajar dilakukan agar guru mampu secara mandiri membuat bahan ajar sehingga pembelajaran di kelas dapat berjalan dua arah seperti yang dikehendaki dalam Kurikulum 2013. Selain itu adanya modul pembelajaran akan meningkatkan kompetensi guru di bidang keahlian administrasi perkantoran dan memperkaya khasanah keilmuan. Secara lebih umum adanya pelatihan ini akan mewujudkan link and match antara sekolah dan perguruan tinggi di bidang keilmuan.

\section{KAJIAN TEORITIK}

\section{Bahan Ajar}

Salah satu faktor keberhasilan proses pembelajaran adalah ketersediaan bahan ajar karena bahan ajar berfungsi sebagai sumber belajar bagi siswa. Hal ini sejalan dengan 
pendapat Prastowo (2014) yang mengemukakan bahwa bahan ajar adalah segala bahan berupa informasi, alat maupun teks yang dirancang secara sistematis dan terarah sebagai upaya pencapaian kompetensi siswa secara menyeluruh yang digunakan selama proses pembelajaran dengan tujuan perencanaan dan penelaahan implementasi pembelajaran.

Fungsi bahan ajar itu sendiri menurut Prastowo (2014) antara lain: (1) dapat digunakan sebagai pedoman bagi pendidik sebagai arahan dalam melakukan aktivitas nya selama proses pembelajaran; (2) merubah fungsi pendidik dari pengajar menjadi fasilitator; (3) proses pembejaran menjadi lebih efektif dan interaktif; (4) siswa menjadi lebih mandiri karena siswa dapat belajar dimana dan kapan saja; (5) aktivitas siswa dapat terarah selama proses pembelajaran.

Bahan ajar berisi tentang kebutuhan yang perlu dipelajari oleh siswa yang berisi konten yang ditulis, dimediasi, atau difasilitasi oleh guru sehingga tujuan pembelajaran dapat tercapai. Jadi bahan ajar disusun berdasarkan kebutuhan pembelajaran dan dibuat untuk menarik perhatian siswa sehingga mereka aktif selama proses pembelajaran berlangsung.

\section{Modul}

Salah satu jenis bahan ajar adalah modul. Modul dapat digunakan sebagai bahan ajar untuk siswa sehingga mereka dapat belajar secara mandiri dengan atau tanpa bantuan guru. Hal ini sejalan dengan pendapat Daryanto dkk (2014) yang menjelaskan bahwa modul merupakan bahan ajar yang disusun secara terprogram dan disajikan secara sistematis dan terperinci sehingga siswa dapat belajar dengan atau tanpa guru atau fasilitator.

Modul dibuat dengan bahasa yang dapat dipahami oleh siswa. Modul berisi materi pelajaran dan indikator pencapaian belajar siswa. Menurut Daryanto dkk (2014) pengembangan modul harus memperhatikan karakteristik modul yang meliputi self instruction, self contained, stand alone, adaptive, dan user friendly. Sedangkan menurut Kurniasih dkk (2014) komponen penyusunan modul antara lain sebagai berikut: (1) Judul; (2) Petunjuk Belajar baik bagi guru maupun siswa; (3) Kompetensi yang akan dicapai; (4) Informasi pendukung; (5) Latihan Soal; (6) Petunjuk kerja; (7) Evaluasi dan Penilaian.

\section{Modul Berbasis Kurikulum 2013}

Pemerintah menetapkan kurikulum 2013 sekitar pertengahan tahun 2013 
sebagai pengganti kurikulum sebelumnya yaitu kurikulum 2006 atau yang dikenal dengan istilah KTSP (Kurikulum Tingkat Satuan Pendidikan). Kurikulum 2013 menerapkan pendekatan scientific learning sebagai pencirian dan menjadi kekuatan adanya kurikulum 2013 (Permendikbud No. 65 Tahun 2013 dalam Kuniasih dkk, 2014). Komponen pada pendekatan scientific learning dikenal dengan $5 \mathrm{M}$ antara lain mengamati, menanya, mengumpulkan data, mengasosiasikan, dan mengkomunikasikan.

Menurut Machin (2014) pendekatan scientific learning menghasilkan beberapa keterampilan diantaranya keterampilan berpikir kritis, keterampilan berkomunikasi, keterampilan melakukan kerja sama dan penyelidikan, dan perilaku berakarakter.

Dari penjelasan di atas dapat disimpulkan bahwa untuk menyusun modul berbasis kurikulum 2013 maka harus memperhatikan unsur dalam penyusunan modul dan menyesuaikan dengan pendekatan scientific learning dengan mengikuti langkah-langkahnya yang meliputi (1) mengamati; (2) menanya; (3) mengumpulkan data; (4) mengasosiasikan, (5) mengkomunikasikan.

\section{MATERI DAN METODE}

\section{Kerangka Pemecahan Masalah}

Available at

http://journal.unj.ac.id/unj/index.php/jpm
Berdasarkan rumusan masalah di atas, maka diperlukan peningkatan kompetensi guru untuk dapat menyusun modul yang relevan dengan kurikulum 2013. Secara ringkas kerangka pemecahan masalah dapat dilihat pada gambar 1 .

Identifikasi Permasalahan:

Keterbatasan Bahan Ajar

Berbasis Kurikulum 2013

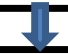

Pelatihan Pembuatan Bahan Ajar Berbasis Kurikulum 2013

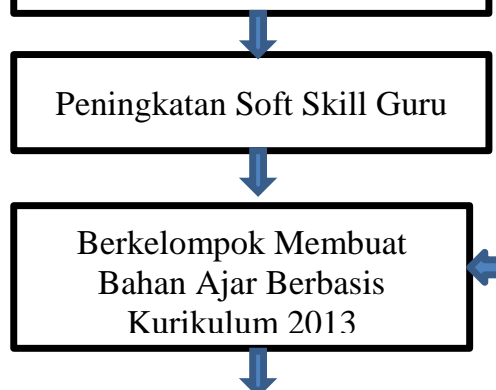

Pendampingan Secara Intensif

Tersedianya Bahan Ajar

Berbasis Kurikulum 2013

Gambar 1. Kerangka Pemecahan Masalah

Berdasarkan gambar 1 Peningkatan kompetensi dosen dapat dilakukan dengan cara pelatihan dan pendampingan secara intensif. Pelatihan ini dilakukan dengan memberikan materi tentang pembuatan modul berdasarkan Kurikulum 2013 sehingga pengetahuan guru akan meningkat. Sedangkan pendampingan dilakukan agar modul yang disusun oleh 
guru sesuai dengan ketentuan, dan tim dapat memberikan masukan yang berarti terkait modul yang disusun.

\section{Realisasi Pemecahan Masalah}

Sesuai dengan kerangka pemecahan masalah, terlebih dahulu yang harus dipersiapkan adalah pelatihan. Tujuan dari pelatihan ini adalah utnuk menambah pengetahuan teoritik guru tentang bahan ajar berbasis Kurikulum 2013. Pelaksanaan pelatihan terdiri dari beberapa tahapan antara lain:

1) Sosialisasi pelatihan kepada guru MGMP administrasi perkantoran di Kabupaten Jombang.

2) Membentuk TIM pelaksana pelatihan

3) Menyusun proposal PKM

4) Menyusun materi pelatihan

5) Melaskanakan PKM dengan meteri pemuatan bahan ajar berbasis Kurikulum 2013.

\section{Khalayak Sasaran}

Pelatihan pembuatan bahan ajar berbasis Kurikulum 2013 diberikan kepada guru-guru SMK Administrasi Perkantoran di Kabupaten Jombang. Tim bekerjasama dengan dinas pendidikan provinsi Jawa Timur untuk melakan sosialisasi tentang kegiatan pelatihan. Kegiatan ini dilakukan sebagai bentuk pengabdian kepada masyarat Jurusan Pendidikan Ekonomi FE Available at http://journal.unj.ac.id/unj/index.php/jpm
UNESA bekerjasama dengan MGMP Pend. Administrasi Perkantoran di Kabupaten Jombang.

\section{Metode}

Metode yang digunakan dalam kegiatan ini adalah pelatihan dan pendampingan. Pelatihan dilakukan secara on class selama 1 hari. Sedangkan pendampingan dilakukan secara off class selama 3 bulan. Pendampingan off class yaitu pendampingan dan konsultasi melalui email, telp, dan whats app.

\section{HASIL DAN PEMBAHASAN}

\section{Hasil}

Kegiatan pengabdian kepada masyarakat dilaksanakan di SMKN 1 Jombang yang beralamat di Jl. Sutomo No. 15 Sengon Jombang. Kegiatan pengabdian kepada masyarakat ini dilakukan dalam bentuk pelatihan dengan metode ceramah dan praktek pembuatan bahan ajar berupa modul berbasis Kurikulum 2013. Kegiatan ini dilaksanakan sebagai upaya untuk meningkatkan kompetensi guru dalam menyusun bahan ajar berbasis kurikulum 2013 dan meningkatkan kualitas pembelajaran. Kegiatan ini ditujukan kepada guru MGMP Administrasi Perkantoran di Kabupaten Jombang sejumlah 52 guru. 
Sebelum melaksanakan pelatihan, tim melakukan penyusunan materi yang akan digunakan dalam pelatihan. Materi untuk pelatihan antara lain:

1. Tujuan pendidikan berdasarkan Kurikulum 2013.

2. Hakekat pembelajaran.

3. Pengertian bahan ajar.

4. Modul.

Selain itu tim juga melakukan pembagian tugas untuk mendampingi pesarta pelatiahan dalam menyusun modul selama off pelatihan. Pendamping dalam penyusunan modul antara lain:

1. Drs. Joni Susilowibowo, M.Pd: pendamping penyusunan modul untuk SMK Negeri Non Administrasi Perkantoran.

2. Durinda Puspasari, S.Pd., M.Pd: pendamping penyusunan modul untuk SMK Negeri Administrasi Perkantoran.

3. Durinta Puspasari, S.Pd., M.Pd: : pendamping penyusunan modul untuk SMK Negeri Administrasi Perkantoran.

4. Triesninda Pahlevi, S.Pd., M.Pd: pendamping penyusunan modul untuk SMK Swasta Administrasi Perkantoran.

Materi pertama yaitu tujuan pendidikan berdasarkan Kurikulum 2013 dan hakikat pembelajaran disampaikan oleh Drs. Joni Susilowibowo, M.Pd. Peserta Available at http://journal.unj.ac.id/unj/index.php/jpm pelatihan menunjukkan respon positif karena pemateri tidak hanya memberikan teori tetapi juga contoh riil sehingga peserta terbangun komunikasi dua arah antara pemateri dan peserta.

Materi kedua tentang bahan ajar dan modul administrasi perkantoran disampaikan oleh Triesninda Pahlevi, S.Pd., M.Pd. Pemateri menyampaikan tentang beberapa bahan ajar yang relevan dan mendukung dalam pembelajaran Kurikulum 2013. Salah satu bahan ajar yang ditekankan adalah pembuatan modul. Pemateri secara sistematis menjelaskan tahapan dalam pembuatan modul, literatur sebagai bahan modul dan contoh modul secara jelas dan terperinci. Pada sesi ini terlihat peserta pelatihan sangat antusias, hal ini terlihat dari banyaknya pertanyaan dari peserta pelatihan.

Setelah selesai materi, peserta dibagi berdasarkan asal sekolah dengan pendamping berasal dari tim yang telah dikelompokkan sesuai dengan cluster sekolah. Peserta diberikan pengarahan bahwa pendampingan akan dilasanakan off class. Selain itu peserta juga diberikan batas penyelesaian modul dan konsultasi selama 1,5 bulan.

Setelah penyampaian teori dan langkah penyusunan modul, peserta 
diberikan kuesioner sebagai salah satu alat ukur peserta tentang pelatihan yang telah diberikan selama on class. Berikut ini adalah respon berdasarkan kuesioner yang diberikan kepada peserta ketika on class:

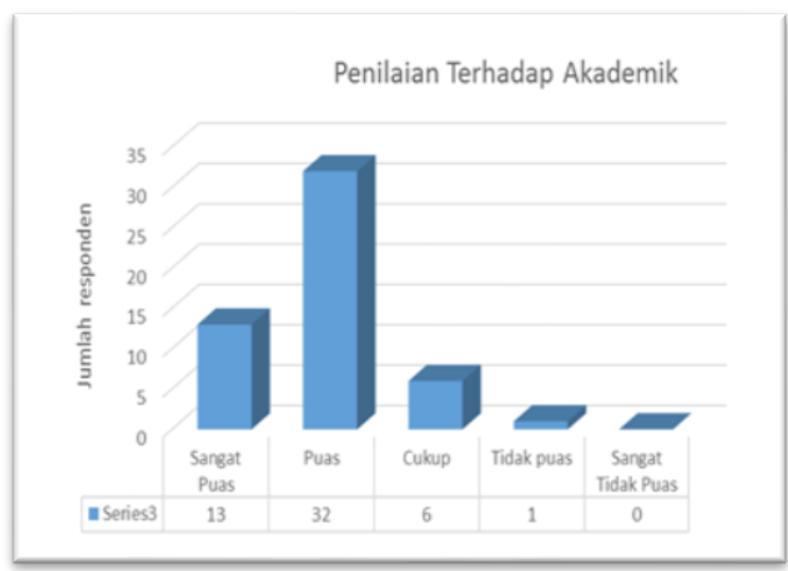

Gambar 2 Penilaian Bidang Akademik

Gambar di atas merupakan rata-rata hasil kuesioner mengenai penilaian akademik dari peserta pelatihan. Kuesioner untuk menilai akademik terdiri dari tujuh pertanyaan yaitu kualitas paparan awal pelatihan, kesesuaian materi dengan tujuan, kesesuaian handout, kualitas urutan penyajian, kecukupan latihan, kesempatan mendapat umpan balik, dan kesempatan peningkatan skill. Berdasarkan gambar 1 Peserta menyatakan bahwa sebanyak $61,6 \%$ puas, $25 \%$ merasa sangat puas, $11,5 \%$ merasa cukup puas, dan sebanyak $2 \%$ tidak puas terhadap materi akademik yang disajikan oleh panitia.

Available at http://journal.unj.ac.id/unj/index.php/jpm
Gambar 3 dibawah ini merupakan hasil rata-rata kepuasan peserta pelatihan pada narasumber.

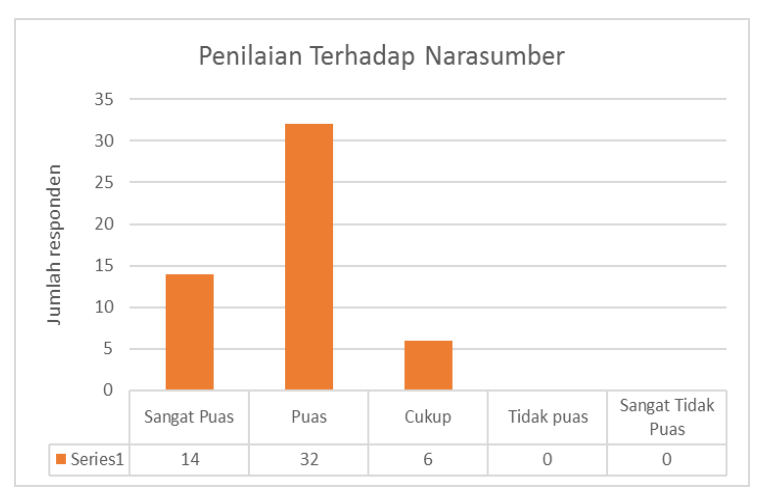

Gambar 3 Penilian terhadap Narasumber

Penilaian narasumber tercermin dari tujuh pertanyaan pada kuesioner yaitu kompetensi di bidang presentasi, efisiensi penyampaian konsep, gaya bahasa yang komunikatif, menyenangkan/variatif, memberikan waktu untuk latihan, memberikan umpan balik, dan ketepatan waktu. Gambar 2 menggambarkan sebanyak 61,5\% peserta pelatihan merasa puas terhadap narasumber pelatihan. Peserta pelatihan merasa sangat puas sebanyak $27 \%$, sedangkan sebanyak 11,5\% merasa cukup puas terhadap penyampaian materi oleh narasumber.

Hasil respon terhadap pengelolaan pelatihan tergambarkan dari tiga pertanyaan dalam kuesioner yaitu layanan umum panitia, fasilitas, dan keterjangkauan lokasi. 
Berkut adalah rata-rata penilaian peserta terhadap pegelolaan pelatihan:

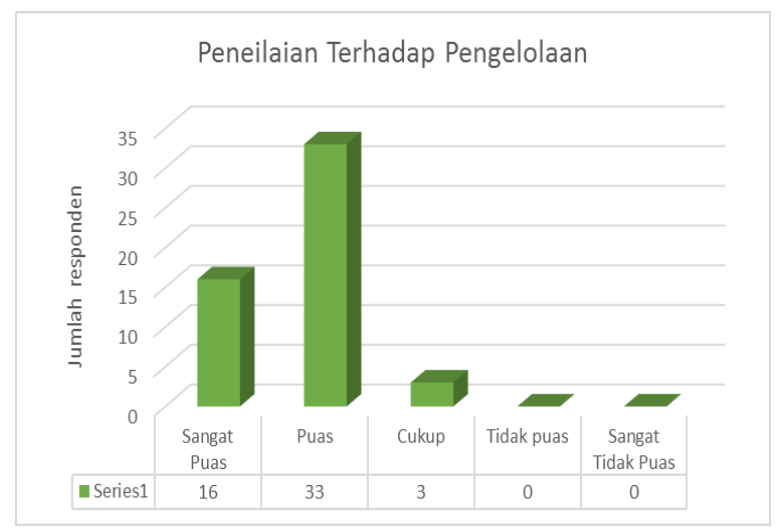

Gambar 4 Penilaian terhadap Pengelolaan

Berdasarkan gambar 4 diketahui bahwa $63,5 \%$ peserta pelatihan merasa puas terhadap pengelolaan pelatihan. Sebesar $30,8 \%$ peserta pelatihan merasa sangat puas, dan sebanyak 5,7\% merasa cukup puas dengan pengelolaan pelatihan.

Selanjutnya respon peserta terhadap keberlanjutan pelatihan dapat tercermin dari gambar dibawah ini:

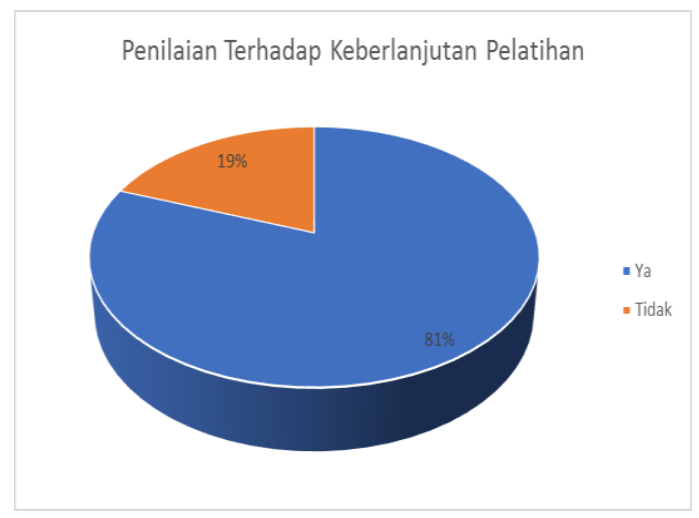

Gambar 5 Keberlanjutan Pelatihan
Berdasarkan gambar diatas diketahui bahwa $81 \%$ peserta menginginkan pelatihan lanjutan untuk pembuatan bahan ajar berbasis kurikulum 2013 karena kurikulum 2013 plus mulai diimplementasikan diseluruh SMA/SMK di Jombang. Peserta pelatihan berharap dengan adanya pelatihan ini mampu membuat bahan ajar sesuai dengan Kurikulum 2013 karena buku ajar berbasis Kurikulum 2013 belum banyak dijual. Sedangkan sisanya sebesar 19\% tidak menginginkan pelatihan lanjutan, tetapi menginginkan pelatihan lain yaitu pembuatan

\section{Pembimbingan}

Kegiatan pembimbingan mulai dilakukan setelah pelatihan berlangsung. Pembimbingan dilaksanakan selama 1,5 bulan. Materi pembimbingan adalah implementasi dalam penulisan modul berdasarkan Kurikulum 2013. Pembimbingan dilakukan melalui email, wahats up, dan telepon. Alamat pengiriman file terpusat pada email triesnindapahlevi@unesa.ac.id. Sedangkan pembimbingan melalui telepon melalui penanggung jawab pada masing-masing kluster sekolah.

Pada tahap pembimbingan off class peserta banyak mengalami kendala dalam hal sumber referensi dan kesibukan aktivitas 
di sekolah. Selain itu kendala waktu yaitu singakatnya masa penyusunan modul membuat banyak draf modul yang masih belum selesai. Sampai dengan batas waktu yang telah ditetapkan yaitu pertengahan bulan September 2017 hanya 1 kelompok yang telah menyelelesaikan modul pembelajaran berbasis Kurikulum 2013. Sedangkan kelompok lainnya masih sebatas konsultasi tentang materi dan sistematika. Peserta memerlukan waktu yang lebih lama untuk bisa menyelesaikan modul yang relevan dengan kompetensi dasar sesuai dengan Kurikulum2013. Hal tersebut Karena beberapa mata pelajaran merupakan mata pelajaran baru yang sebelumnya belum ada di SMK untuk keahlian administrasi perkantoran.

\section{Luaran yang Dicapai}

Berdasarkan hasil dari pelaksanaan PKM, maka luaran yang dicapai antara lain:

1. Meningkatkan kompetensi guru di bidang pembuatan bahan ajar yang sesuai dengan Kurikulum 2013.

2. Tersusunnya Draf Modul yang Relevan dengan Kurikulum 2013

\section{Sertifikat untuk Peserta}

Sertifikat akan diberikan kepada seluruh peserta yang rutin untuk melakukan konsultasi dalam menyusun draf modul sesuai dengan Kurikulum 2013.

Available at http://journal.unj.ac.id/unj/index.php/jpm

\section{KESIMPULAN DAN SARAN}

\section{Kesimpulan}

Berdasarkah hasil pembahasan diatas, dapat disimpulkan antara lain:

1. Pelaksanaan pengabdian kepada masyarakat berupa pembuatan bahan ajar berbasis Kurikulum 2013 terlaksana sesuai tujuan dengan jumlah peserta sebanyak 52 guru.

2. Draf modul yang berhasil diselesaikan dalam pendampingan sebanyak 1 draf modul, sedangankan lainnya masih proses revisi.

\section{Saran}

Pemahaman tentang penysusunan bahan ajar berbasis Kurikulum 2013 dalam hal ini adalah modul dapat ditingkatkan dengan melakukan pembimbingan dan praktek berkelanjutan. Kegiatan ini perlu di dukung dari lembaga terkait untuk memberikan fasilitas dan pelatihan yang berkala dan berkelanjutan sehingga guru memiliki kompetensi yang memadai untuk menyusun bahan ajar sehingga kualitas pembelajaran dapat ditingkatkan

\section{DAFTAR PUSTAKA}

Alawiyah, F. 2014. Kesiapan Guru dalam Implementasi

Kurikulum 2013. Jurnal, 6.

Daryanto, dkk. 2014. Pengembangan Perangkat Pembelajaran: Silabus, 
RPP, PHB, Bahan Ajar. Yogyakarta: Gava Media.

Dick, W dan Carey, L (2009). The Systematic Design of Instruction. Fifth Edition. New Jersey: Pearson Education Inc.

Indonesia, P. R. 2003. Undang-undang Republik Indonesia Nomor 20 Tahun 2003 tentang Sistem Pendidikan Nasional.

Kurikulum, P., dan Depdiknas, B. 2002. Kurikulum Berbasis Kompetensi. Jakarta, Balitbang Depdiknas. 2002: "Kurikulum dan Hasil Belaior" Kompetensi Dasar Mata Pelajaran Matematika Sekolah Menengah Pertama dan Madrasah Tsanawiyah: I Jakarta, Balitbang Depdiknas.

Kurniasih, I., dkk. 2014. Implementasi Kurikulum 2013: Konsep dan Penerapan. Surabaya: Kata Pena.

Kurniasih, I., dkk. 2014. Panduan Membuat Bahan Ajar Buku Teks Pelajaran Sesuai dengan Kurikulum 2013. Surabaya: Kata Pena.

Machin, A. 2014. Implementasi Pendekatan Saintifik, Penanaman Karakter dan Konservasi pada Pembelajaran Materi Pertumbuhan. Jurnal Pendidikan IPA Indonesia, 3(1).

Mulyasa, Enco. 2008. Implementasi Kurikulum Tingkat Satuan Pendidikan: Kemandirian Guru dan Kepala Sekolah. Bumi Aksara.

Oates, T. 2011. Could Do Better: Using International Comparisons to Refine The National Curriculum in England. Curriculum Journal, 22 (2), 121-150.

Prastowo, A. 2014. Panduan Kreatif Membuat Bahan Ajar Inovatif. Jakarta: Diva Press.

Sani, R. A. 2014. Pembelajaran Saintifik untuk Implementasi Kurikulum 2013.
Suwarno, E. 2012. Perubahan Kurikulum: Refleksi dan Tantangan bagi Jurusan Teknik Sipil dalam Pengembangan Kurikulum. Teknologi dan Kejuruan, 34 (2).

Voogt, J., dan Roblin, N. P. 2012. A Comparative Analysis of International Frameworks for 21st Century Competences: Implications for National Curriculum Policies. Journal of Curriculum Studies, 44 (3), 299-321. 